\title{
Research on the Flexible Employment Policy and the Linkage Mechanism of the Private Colleges and Universities in Shaanxi Province
}

\author{
Hao Yafen \\ Qifang Education Research Institute, Xi'an International University
}

Keywords: private colleges and universities in Shaanxi Province; graduate; flexible employment policy

\begin{abstract}
By researching the current situation of the employment of private colleges and universities in Shaanxi Province, this paper discusses the current situation and problems about the employment of private colleges and universities; it finds out the original reasons, and then, puts forward some countermeasures such as improving working mechanism, improving talent training model and establishing employment feedback mechanism and so on, so as to provide some advices for optimizing the flexible employment policy and the linkage mechanism of private colleges and universities in Shaanxi Province.
\end{abstract}

In the period of economic transformation, the situation of the employment of graduates who are the students of private colleges and universities in Shaanxi Province has had the trend of diversification. As the form of employment becomes diversified, flexible employment has been gradually concerned by the graduates of colleges and universities, especially by the graduates of private colleges and universities. How to provide relevant policy support and how to develop the linkage mechanism for those graduates who are going to choose flexible employment has become an important issue that needs to be highlighted.

\section{Analysis on the Current Situation of Flexible Employment of Private Colleges and Universities' Graduates in Shaanxi Province}

The employment forms of the graduates in Shaanxi Province are diversified. In the Annual Report on Employment Quality of College and University Graduates in Shaanxi Province 2017, which was published by Students' Affair Office of Education Department of Shaanxi Provincial Government, West China Higher Education Evaluation Centre of Xi'an Jiaotong University and Shanxi Province Higher Education Data Centre, it manifests that----in 2017, there are 83072 graduates who come from 29 private colleges or universities(these schools include private undergraduate universities, private independent colleges and private higher vocational colleges) had graduated from the schools. In these private schools, the employment rate of private undergraduate schools and independent colleges was $90.40 \%$, and the employment rate of private vocational and technical colleges was $81.63 \%$. It can be seen from the report that some graduates of the private colleges and universities in Shaanxi Province have not been employed. According to the research report, the employment forms of the graduates in Shaanxi Province mainly include signing employment agreements, employment in other forms, signing labor contracts, freelancing, scientific research assistants, national grass-root projects, self-employment, local grass-roots projects and so on. So to speak, the graduates' employment forms in Shaanxi Province are diversified.

Employment pressure of the graduates is heavy. At present, the Provincial Education Department has issued the Notice on Promoting the Employment and Startup of the Ordinary University Graduates in 2018, in this notice, it points out that the total quantity of the graduates in Shaanxi Province will reach 362,000, and the employment pressure of the graduates is very heavy. Shaanxi, as a large province of private higher education, has nearly 100,000 graduates every year. Because of the limited posts of public service units and the governmental departments, it is impossible to provide so many posts to the graduates at the same time. To solve this problem, it is necessary to encourage a part of graduates to find jobs in other forms. Hart, a famous American Specialist on 
socioeconomics believes that the producing units which are small and not organized well, and which paid relatively lower salary to the employee in developing countries can create more jobs and relieve the employment pressure to some extent.

The environment for flexible employment of the graduates is good. The starting point of the ancient Silk Road is in Shaanxi Province, it is also the bridge of cultural exchanges and communication between the East and the West; now, it is driving the train of "The Belt and Road" and transporting these products of "made in Shaanxi" to the countries along "The Belt and Road". Under this background, there must be more working opportunities in Shaanxi. At the some time, according to the report of the economy operation of Shaanxi that was published by the Bureau of Statistics of Shaanxi Province, we can know that----in 2017, the GDP of Shaanxi reached 2.189881 trillion Yuan; this is the first time that the GDP of Shaanxi has reached one trillion; so, the economy of Shaanxi has great developmental potential in the future.

The Shaanxi Provincial Education Department issued a notice on emphasizing the implementation of employment and startup plan of the graduates, so as to actively serve the strategic development of China and Shaanxi, to actively find out more forms of employment in grass-roots units and promote the innovation work and startup work in an all-round way. Therefore, the flexible employment of the colleges and universities in Shaanxi will have a better future.

\section{Analysis on Problems and Causes of Flexible Employment of Private College Graduates in Shaanxi Province.}

Everything has two sides, the flexible employment of college graduates has its advantages, but at the same time, there are still some problems in the process of its development.

As one of the regions where private colleges and universities are concentrated, many graduates choose flexible employment every year. However, there are still many problems in the process of flexible employment.

Prejudice of ideological understanding. From the perspective of society, some people have prejudices to flexible employment, they discriminate flexible employment; from the perspective of graduates of the private colleges and universities, these graduates do not have good understanding about the position of their schools and themselves, and they are lack of confidence, so that they have some biases on flexible employment.

Problems on policy. In the aspect of flexible employment, although a series of policies have been issued and have been highlighted from the central government to the local government, but many policies have not been implemented effectively because of the coordination and communication problems among the relevant departments in the process of the implementation, so that the expected effect was not achieved.

The abilities of startup and employment of the private colleges and universities' graduates in Shaanxi Province need to be improved further. The comprehensive quality of the private colleges and universities' students is usually weaker than the public schools; in addition, every student's professional ability is different, so the graduates of the private colleges and universities usually feel difficult to find a satisfied job. Therefore, in order to improve the graduates' ability of flexible employment, it is urgent to improve the startup and employment abilities of the private college and universities' graduates, to gradually reduce the gap between the private schools and the top schools, to reduce the gap between the students of private schools and the students who do well in employment, and then to promote the development of flexible employment. Problems on employment feedback and the linkage mechanism. At present, although there are some corresponding annual employment reports in Shaanxi, but there is no deep analysis and feedback on the problems of the report.

To sum up, it can be seen that Shaanxi has a series of problems in flexible employment. How to improve the flexible employment policy and the linkage mechanism has become a problem need to be discussed and solved. 


\section{Strategies of Constructing the Flexible Employment Policy and the Linkage Mechanism for Graduates of Private Colleges and Universities in Shaanxi Province}

The propaganda and implementation of the flexible employment policy of the graduates in Shaanxi private colleges and universities, the coordination and communication of relevant departments, and the construction of feedback and supervision mechanisms can promote the further healthy development of flexible employment to some extent.

On the one hand, from the perspective of whole society, it is necessary to make the whole society is aware of the structural contradictions between the employment pressure faced by the graduates of the private colleges or universities in Shaanxi and the demand of market. As an effective way to promote employment, flexible employment deserves recognition of the society. On the other hand, from the perspective of college and university graduates, the colleges and universities should not only improve the professional quality of the graduates, but also focus on the graduates' self-confidence and resistance to frustration, so as to guide them to have a good understanding of the new way of employment.

To promote the deep integration of the education which focuses on innovation and startup and the vocational education, to integrate this kind of education that highlights innovation and startup into the whole process of talent cultivation, to further enhance the employment and startup abilities of the graduates, so that the schools and the graduates could serve the local economy better.

It is necessary to strengthen the synergetic and practical education mechanism, so as to cultivate the graduates' ability of coordination and cooperation. It is also necessary to form the combination of policy, industry, education and scientific research, so that the private colleges and universities in Shaanxi Province could cooperate with the public universities, scientific research institutes and relevant industrial enterprises for training the high-level and high-quality graduates. It is important to cultivate the students by means of practical activities that are organized by these relevant organizations. On the one hand, it is necessary to cultivate the students' ability according to the needs of the society, to cultivate the students' ability of communication, teamwork and scientific thinking during the period of school, so that they can adapt to challenges and changes; on the other hand, it is also necessary to strengthen the construction of practice base out of the schools, to encourage teachers to practice in the departments of enterprises, and to improve the practical ability of students and teachers constantly, so as to promote the abilities of the graduates.

In Shaanxi Province, some of the graduates of private colleges and universities solve the employment problem by startup or self-employment. However, in the process of starting a business, they will encounter many problems such as shortage of funds, which greatly blocks the further development of their business, so they need special policy support from the government and related departments, such as financial assistance, favorable taxation, and financial support from flexible employment funds and so on. At the some time, the optimization and adjustment of the fiscal structure of the fiscal expenditure, and the overall arrangements to make the best use of all aspects of funds such as talent development, employment, etc., these all could provide financial support for flexible employment of the graduates of the private colleges and universities.

To do a good job on flexible employment requires the cooperation of relevant government departments and the schools. Local governments should make an overall planning so as to guide and encourage the graduates to adopt flexible employment policy. At the some time, the government should also establish and improve a coordination mechanism that is led by the relevant government departments and other relevant units. The departments of human resource should response for the overall arrangement and strengthen the coordination between all the participators. All relevant units should know their responsibilities clearly and actively participate in this work so as to promote the all round development of this work.

First, to strengthen the statistics and analysis of flexible employment data of private colleges and universities' graduates in Shaanxi Province, to use the correct data and make sure the reliability of these data about flexible employment. Second, to compile the annual employment statistics report according to all the data of the private colleges and universities in Shaanxi Province. In order to reflect the actual employment situation and features of private college graduates in Shaanxi 
province, the annual report must contain some necessary and detailed items such as employment rate, employment posts, satisfaction degree, and startup situation etc. Third, the relevant departments and universities should constantly improve their working methods, improve their working efficiency, and actualize the timely updating of the flexible employment data. At last, it is crucial to constantly analyze the relevant data about flexible employment and startup, and to provide effective services for the decision making of the government and the private schools. To establish the feedback mechanism for tracing the employment situations of the graduates, and to establish the dynamic adjustment mechanism for adjust the strategy of the private colleges and university in some aspects such as employment, recruiting students, and set up the majors of these schools, so as to promote the internal reform of these private schools on recruiting students and cultivating the talents, and to promote the harmonious development between the talent cultivation and the economic development of Shaanxi Province.

In order to further promote flexible employment ability of the graduates, it is necessary to constantly improve the employment service system. The first is to provide all relevant information on job introduction, to guide and cultivate the graduates by mean of the data so as to improve their professional ability and then realize flexible employment. The second is to increase the public welfare post and promote the development of it, so as to achieve flexible employment of the graduates. At last, to speed up the construction of employment service network, the network can record the specific information of the graduates, and provide more suitable posts to the graduates by means of the service network.

On the one hand, it is necessary to strengthen the construction of the majors. Major is the basic segment of the talent cultivation, and it is the most crucial factor that influence the development of a college or university. In order to construct some top majors, it is necessary to let the majors become more suitable for the need of the society, to cultivate the students according to cultivation plan and ensure the quality so as to achieve the cultivation objectives. At the some time, it is necessary to make sure the teaching resources are enough so as to improve the degree of satisfaction of the students and the society. On the other hand, it is necessary to establish the early warning system and the checking and feedback system of the graduates' employment, to improve the annual report system that focus on the employment of the graduates and the supply and demand of talents in some key industries so as to dynamically adjust the scale of the enrollment of the colleges and universities.

Of course, In order to fundamentally improve the flexible employment policy and its linkage mechanism of private universities in Shaanxi Province, it is necessary not only to have a good policy environment, but also to unify ideas and deepen the understanding among the private colleges and universities, and to highlight flexible employment policy and the important role of linkage mechanism in the process of improving the talents' abilities. The administrative departments that is related to education should adjust relevant policies in time, provide relevant policies for the employment of graduates of private colleges and universities in Shaanxi; at the some time, the departments should try their best to strengthen the cooperation with other relevant departments, and promote the healthy development of the flexible employment of private colleges and universities' graduates in Shaanxi Province by the communication and exchange of information.

\section{Conclusion}

On the basis of analyzing and judging the situation of flexible employment of the private colleges and universities in Shaanxi Province, this paper analyzes and discusses the problems existing in flexible employment and its original causes, and then puts forward some suggestions for improving the flexible employment policy and the linkage mechanism for graduates of colleges and universities. Of course, with the constant development of social transformation, the graduates of private colleges and universities in Shaanxi will have the working opportunities that are a lot of forms, and the flexible employment will also have great developmental potential. The discussion of this issue will provide some ideas for the flexible employment of private college and university graduates in Shaanxi Province to some extent. 


\section{Acknowledgement}

Scientific Research Program Funded by Shaanxi Provincial Education Department (Program No. 14JZ042)

\section{References}

[1] 1. Hart, Informal Income Opportunities and Urban Employment in Camda[J], Journal Modem African Studaies,1973(11): 33-37.

[2] Liu Jun, Zhu Huirong, Gan Wei. Research on Flexible Employment Policy of the University Graduate[J]. Education for Chinese After-school, 2014, (33): 36-37.

[3] Views of the Central Committee of CCP on Further Guiding and Encouraging Graduates of Colleges and Universities to work at the Grass-roots Units, 2017.

[4] Annual Report on Employment Quality of College and University Graduates in Shaanxi Province 2017 has been Published. http://www.snedu.gov.cn/jynews/jyyw/201802/06/75721.html

[5] Zhang Yan. Exploration and Analysis on Flexible Employment of College and University Graduates under the New Situation[J]. Research in Teaching, 2010(04).

[6] Six Key Words to Understand the Economy of Shaanxi Province in 2017. http://www.rmzxb.com.cn/c/2018-01-26/1942101.shtml

\section{About the Author:}

Hao Yafen (1984-), comes from Xi’an, Shaanxi Province.

Title: Assistant Researcher of Qifang Education Research Institute, Xi'an International University

Research Direction: Private Higher Education; Ideological and Political Education 